\title{
Technological Implementation for Increasing the Production Effecitivity
}

\author{
M. Shanmugapriya, S .Mari, K. Thiyagarajan
}

\begin{abstract}
This study seeks to assess benchmarking in enhancing organizational performance. For the study, a survey research model has been adopted. Questionnaires have been issued to 60 DALMIA Cement management staff. The formulated theories are evaluated using the application of Pearson's correlation. The outcome revealed that benchmarking helps in improving product quality, increasing customer's satisfaction level, increasing profitability and enlarging market share. In order to make appropriate use of benchmarking technique and enjoy its benefits, the research recommended that organizations should follow meticulously the steps in the benchmarking process, effectively communicate the requirements for change to employees in the organization, maintain the ethics of conduct in benchmarking and successfully eliminating the challenges and barriers in benchmarking to ensure that the cost of benchmarking is not higher than the benefits thereof.
\end{abstract}

Keywords: Benchmarking, Hypothesis, six sigma.

\section{INTRODUCTION}

Benchmarking is the process of comparing your own organization, operations or processes with other organizations in your industry or the wider marketplace[1]-[6]. Benchmarking can be applied against any product, process, function or approach in business. Common focal points for benchmarking initiatives include measures of time, quality, cost and effectiveness, and customer satisfaction.

Benchmarking helps to contrast your own operations with competitors ' operations and generate ideas to enhance procedures, strategies, and technology to reduce costs, increase profits, and reinforce customer loyalty and satisfaction. Benchmarking, like Six Sigma, is an important component in performance and management programs[7]-[10].

\section{OBJECTIVES}

The main goal of this research is to review the impact of benchmarking on the organizational performance. However, the specific objectives are

i. To determine whether benchmarking helps in improving product quality in Dalmia Cement.

Revised Manuscript Received on December 11, 2019

M. Shanmugapriya, Department of Science and Humanities, Bharath Institute of Higher Education and Research, Chennai, India. Email: priyashammu@gmail.com

S.Mari, Department of Science and Humanities, Bharath Institute of Higher Education and Research, Chennai, India. Email: maripalani09@gmail.com

K. Thiyagarajan, Department of Science and Humanities, Bharath Institute of Higher Education and Research, Chennai, India. Email: thiyagu768@gmail.com ii. To determine whether benchmarking helps in increasing customer satisfaction level in Dalmia Cement.

iii. To determine whether benchmarking helps in improving profitability in Dalmia Cement[11]-[15].

iv. To determine whether benchmarking helps in increasing market share in Dalmia Cement.

\section{RESEARCH METHODOLOGY}

Research questions are objections that arise from stating the research objectives. They are questions which the study seeks to answer. Therefore, the research questions relating to this work are:

i. To what extent does benchmarking help in improving product quality in Dalmia Cement?

ii. To what extent does benchmarking help in increasing customer's satisfaction level in Dalmia Cement?

iii. To what extent does benchmarking help in improving profitability in Dalmia Cement?

iv. To what extent does benchmarking help in increasing market share in Dalmia Cement?

\section{RESULTS AND DISCUSSIONS}

The responses gathered from the field via the questionnaire are presented and analyzed using the tables below:

\begin{tabular}{|l|l|l|}
\hline Response & Frequency & Percentage (\%) \\
\hline Strongly agree & 19 & 38 \\
\hline Agree & 25 & 50 \\
\hline Disagree & 5 & 10 \\
\hline $\begin{array}{l}\text { Strongly } \\
\text { disagree }\end{array}$ & 1 & 2 \\
\hline Total & $\mathbf{5 0}$ & $\mathbf{1 0 0}$ \\
\hline
\end{tabular}

Table - 1 Respondents view as to whether it is important for Dalmia Cement Plc. Plant to benchmark product quality of its competitors.

It can be seen from table 1 above that 44 respondents, $88 \%$ of the respondents, agreed that it is important for Dalmia Cement Plc to benchmark the product quality of its competitors, while six respondents representing $12 \%$ disagree[16]-[21]. 


\begin{tabular}{|l|l|l|}
\hline Response & Frequency & Percentage (\%) \\
\hline Strongly agree & 17 & 34 \\
\hline Agree & 32 & 64 \\
\hline Disagree & 1 & 2 \\
\hline Strongly disagree & - & 0 \\
\hline Total & $\mathbf{5 0}$ & $\mathbf{1 0 0}$ \\
\hline
\end{tabular}

Table- 2 Respondents view as to whether it is important for

Dalmia Cement Plc has been benchmarking the product quality of its competitors.

From table 2, 98\% of the respondent constituting 49 respondents agreed that Dalmia Cement Plc has been benchmarking the product quality of its competitors while the remaining $2 \%$ which constituted one respondent disagreed.

\begin{tabular}{|l|l|l|}
\hline Response & Frequency & Percentage (\%) \\
\hline Strongly agree & 10 & 20 \\
\hline Agree & 39 & 78 \\
\hline Disagree & 1 & 2 \\
\hline Strongly disagree & - & 0 \\
\hline Total & $\mathbf{5 0}$ & $\mathbf{1 0 0}$ \\
\hline
\end{tabular}

Table - 3 Respondents view as to whether benchmarking has helped improved the quality of Dalmia Cement Plc.

Table 3 showed that 49 respondents agreed that benchmarking has helped Dalmia Cement Plc improve the quality of its products. This makes up $98 \%$ of the respondents, while the remaining respondents making up $2 \%$ of the respondents disagreed.

\section{RESULTS AND DISCUSSIONS}

This study assessed benchmarking in enhancing organizational performance with focus on dalmia Cement Plc. The study revealed that enormous benefits such as improvement in product quality, increased customer satisfaction level, increased profitability and increased market share derived from the application of benchmarking in corporate organization like Dalmia cement .Dalmia cement plc, has benchmarked its products, services and operation. Therefore, it is important to stress that, benchmarking is the best practice generates and teaches organization new lessons in competitiveness[22]-[25]. It exposes them to new marketing strategies, production and operations techniques, and techniques in human resource management.

\section{CONCLUSION}

The focal point of the study is to assess benchmarking in enhancing organizational performance. It was found that application of benchmarking in corporate organization indeed helps in improving organizational performance in areas of product quality, customer satisfaction, profitability and market share of any business organization.

\section{REFERENCES}

1. Vasanthi, S. \& Rabiyathul Basariya, S. 2019, "Influence of value analysis and cross training in industry", International Journal of Engineering and Advanced Technology, vol. 8, no. 6, pp. 1810-1811.

2. Velvizhi, R., Sri Gowtham, S. \& Jeya Priya, D. 2019, "Examination of early feedbacks for effective product retailing on E-commerce websites", International Journal of Engineering and Advanced Technology, vol. 8, no. 6 Special Issue 2, pp. 703-706.

3. Anuradha, C., Pothumani, S. \& Kavitha, R. 2019, "A novel method towards E-commerce", International Journal of Engineering and Advanced Technology, vol. 8, no. 6 Special Issue 2, pp. 535-538.

4. Thomas, J. \& Rabiyathul Basariya, S. 2019, "A study on the issues of financial ratio analysis", Indian Journal of Public Health Research and Development, vol. 10, no. 3, pp. 1079-1081.

5. Ramachandran, S. \& Rabiyathul Basariya, S. 2019, "Online marketing study on customer satisfaction and relationship", Indian Journal of Public Health Research and Development, vol. 10, no. 3, pp. 1072-1078.

6. Priya, R., Vinothini, G. \& Cor Jesu, C.D. 2019, "The mentor-protégé relationship for professional growth", Journal of Advanced Research in Dynamical and Control Systems, vol. 11, no. 9 Special Issue, pp. 1110-1119.

7. Jannifer Rani, N., Bina Pani, S. \& Nimisha, N.S. 2019, "A study on money back polices available in LIC", Journal of Advanced Research in Dynamical and Control Systems, vol. 11, no. 9 Special Issue, pp. 833-839.

8. Saillaja, V., Jhansi Rani, K. \& Catherine, R. 2019, "Global marketing management planning and organization", Journal of Advanced Research in Dynamical and Control Systems, vol. 11, no. 9 Special Issue, pp. 489-493.

9. Saillaja, V., Jhansi Rani, K. \& Catherine, R. 2019, "The new phase of marketing information system", Journal of Advanced Research in Dynamical and Control Systems, vol. 11, no. 9 Special Issue, pp. 482-488.

10. Thoufiqulla \& Raju, D.V. 2019, "Perception of indian investor towards investment in mutual funds with special reference to mip funds", Journal of Advanced Research in Dynamical and Control Systems, vol. 11, no. 5, pp. 177-183

11. Jasmine, K.R.M. \& Basariya, S.R. 2018, "A study on the customers benefits on mutual funds", International Journal of Civil Engineering and Technology, vol. 9, no. 4, pp. 45-48.

12. Vasanthi, S. \& Basariya, S.R. 2019, "Pros and cons of on the job training versus off the job training", International Journal of Scientific and Technology Research, vol. 8, no. 10, pp. 671-674.

13. Pavithra, J. \& Ganesan, M. 2016, "A study on awareness and impact of micro-financial schemes", International Journal of Applied Business and Economic Research, vol. 14, no. 8, pp. 5449-5460.

14. Pavithra, J., Dilli Babu, P. \& Ambuli, T.V. 2014, "A study on budgetary control at Maruti Service Masters, Chennai", International Journal of Applied Business and Economic Research, vol. 12, no. 2, pp. 151-161.

15. Gunaraja, T.M. \& Venkatrama Raju, D. 2018, "Determining factors of organisational climate with reference to leadership styles", International Journal of Mechanical Engineering and Technology, vol. 9, no. 9, pp. 1327-1332.

16. Gunaraja, T.M. \& Venkatrama Raju, D. 2018, "The role of job satisfaction and training of employees in determining organisational climate of a selected industry", International Journal of Civil Engineering and Technology, vol. 9, no. 8, pp. 1266-1269.

17. Aarathy, T.S. \& Raju, D.V. 2018, "Performance appraisal and its effects on employees with respect to it sector in Chennai city", International Journal of Civil Engineering and Technology, vol. 9, no. 6, pp. 1535-1538.

18. Aarathy, T.S. \& Raju, D.V. 2018, "Employee perception towards performance appraisal system in IT sector", International Journal of Mechanical Engineering and Technology, vol. 9, no. 5, pp. 131-135.

19. Porselvi, W., Jublee, D. \& Sivanesan, G. 2018, "A study on factors influencing adoption of technology and innovation in banking industry, tamilnadu, India", International Journal of Mechanical Engineering and Technology, vol. 9, no. 5, pp. 789-800.

20. Akessa, G.M. and Dhufera, A.G., 2015. Factors That Influences Students Academic Performance: A Case of Rift Valley University, Jimma, Ethiopia. Journal of Education and Practice, 6(22), pp.55-63.

21. Miller, G. and Shih, C.C., 1999. A faculty assessment of the academic rigor of on-and off-campus courses in agriculture. Journal of Agricultural Education, 40, pp.57-65. 
22. Tsinidou, M., Gerogiannis, V. and Fitsilis, P., 2010. Evaluation of the factors that determine quality in higher education: an empirical study. Quality Assurance in education, 18(3), pp.227-244.

23. Farooq, M.S., Chaudhry, A.H., Shafiq, M. and Berhanu, G., 2011. Factors affecting students' quality of academic performance: a case of secondary school level. Journal of quality and technology management, 7(2), pp.1-14.

24. Fitsilis, P., Gerogiannis, V. and Anthopoulos, L., 2014. Ontologies for software project management: a review. Journal of Software Engineering and Applications, 7(13), p.1096.

25. Adams, J.D. and Jaffe, A.B., 1996. Bounding the effects of R\&D: an investigation using matched establishment-firm data(No. w5544). National bureau of economic research.

\section{AUTHORS PROFILE}

M. Shanmugapriya Assistant Professor, Department of Science and Humanities, Bharath Institute of Higher Education and Research, Chennai, India.

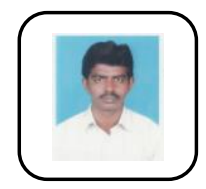

S.Mari Assistant Professor, Department of Science an Humanities, Bharath Institute of Higher Education and Research, Chennai , India.

K. Thiyagarajan Assistant Professor, Department of Science and Humanities, Bharath Institute of Higher Education and Research, Chennai , India. 